\title{
What makes a fertile sperm? Unique molecular attributes of stallion fertility
}

\author{
Róisín A Griffin, Mark Baker, Robert John Aitken, Aleona Swegen and Zamira Gibb \\ Priority Research Centre for Reproductive Science, University of Newcastle, Newcastle, New South Wales, Australia \\ Correspondence should be addressed to Z Gibb; Email: Zamira.Gibb@newcastle.edu.au
}

\begin{abstract}
Stallions experience lower per-cycle conception rates compared to other livestock species, largely because they are selected for breeding based on athletic prowess and not reproductive fitness. Mares are seasonal breeders, and pregnancies cannot be detected until 10-14 days post cover via transrectal ultrasonography. This means the detection of stallion fertility fluctuations is delayed by at least 2 weeks, which within the short breeding season employed by the thoroughbred horse breeding industry, can prove quite costly. For these reasons, there is increased demand for robust laboratory assays aimed at the accurate assessment of stallion fertility. This paper reviews our existing knowledge concerning the molecular mechanisms that underpin the functional competence of stallion spermatozoa, highlighting the relative importance of oxidative stress, DNA damage, sperm proteomics and RNA profile. We also consider the way in which fundamental improvements in our understanding of stallion sperm biology are informing the identification and development of possible biomarkers of fertility and thus avenues for the development of specific assays for fertility prediction. Reproduction (2019) 158 R125-R137
\end{abstract}

\section{Introduction}

The selection of horses for breeding is based on athletic performance and pedigree, rather than reproductive fitness. As a result, similar to humans, there is virtually no selection pressure for fertility (Parlevliet \& Colenbrander 1999, Morris \& Allen 2002, Novak et al. 2010, Gibb et al. 2014), and therefore, per-cycle conception (PCC) rates are generally lower than those observed for other domestic livestock species at around 60\% (Nath et al. 2010).

The thoroughbred horse industry is unique from other horse breeding industries in that all registered foals must be produced via natural breeding and the use of assisted reproductive technologies is strictly forbidden. Furthermore, there are strict breeding seasons implemented by the industry in the northern and southern hemispheres. Foals born early in the season gain a chronologic and physiological advantage over late born foals in both the sales ring (Robbins \& Kennedy 2001, Pagan et al. 2005) and at the race track (Oki et al. 1994, Gramm \& Marksteiner 2010, Takahashi 2015), thus placing immense pressure on breeders to produce foals as close to the start of the season as possible.

A dependence on natural breeding means that popular stallions will breed up to four times a day. Any decrease in fertility resulting in a failed conception exacerbates the breeding pressure placed on stallions, as mares will have to be rebred on the following oestrous cycle. The ability to predict the existence of subfertility would allow management personnel to better tailor the breeding regimens of individual stallions in order to maximise PCC rates. Although the samples cannot be used for insemination, semen from thoroughbred stallions is routinely collected for the purpose of performing semen assessments throughout the season. While conventional sperm assays, such as sperm concentration, motility and morphological assessments are a valuable first port-of-call for identifying subfertile stallions, they provide only moderate information on the functional competence of sperm cells (Petrunkina et al. 2007), and can be deleteriously affected by poor collection and handling techniques which result in a sample that is not representative of the original ejaculate. The use of more robust molecular assays which are not affected by post-ejaculatory handling would provide a more comprehensive understanding of the fertilising potential of the spermatozoa and a more reliable indication of any inter-ejaculation variation in fertility.

In this review, we provide an overview of recent developments in our understanding of molecular mechanisms that dictate sperm function in the horse that might potentially serve as clinically-useful indicators of a thoroughbred stallion's fertility. This includes aspects of sperm metabolism and its relationship with oxidative damage, the susceptibility of sperm DNA and proteins to the downstream effects of reactive oxygen species (ROS), the role of the sperm proteome in defining the fertilising potential of the spermatozoa and the emerging contributions of various RNA species to sperm function. 


\section{Sperm metabolism and oxidative damage}

Like all cells, spermatozoa exist under aerobic conditions and, as a consequence, are faced with the oxygen paradox; oxygen is necessary for sustained life, but metabolites of oxidative processes, when present in high quantities, endanger the cell's survival (Baumber et al. 2000, Aitken et al. 2012b, Chandra et al. 2012). In comparison to human and mouse spermatozoa which predominantly use glycolysis to generate ATP, equine spermatozoa mainly employ oxidative phosphorylation (OXPHOS) for this purpose (Gibb et al. 2014). OXPHOS can generate approximately 36 ATP molecules in the metabolism of glucose compared to only two ATP molecules produced using glycolysis. Therefore, OXPHOS facilitates significantly faster motility, with stallion spermatozoa recording velocity parameters $60 \%$ higher than those of glycolytic human spermatozoa (Gibb et al. 2014). ROS are generated spontaneously by the cell as by-products during normal mitochondrial metabolism. These include the superoxide anion, nitric oxide and hydrogen peroxide, all of which are important signalling molecules in many cellular processes such as tyrosine phosphorylation during sperm capacitation (Dalle-Donne et al. 2003, Koppers et al. 2008, Aitken et al. 2010a).

The increased mitochondrial activity facilitated by OXPHOS results in a high rate of ROS generation. Although the sperm cell has a unique matrix of antioxidants which allow it to neutralise free radicals, this ability is lost over time once the antioxidant defences become overwhelmed (Gibb et al. 2016). Eventually the continued, unchecked production of these reactive molecules will lead to the perturbation of cellular functions (Baumber et al. 2000, Dalle-Donne et al. 2003, Aitken et al. 2010b), which can lead to motility loss and oxidative DNA damage, a phenomenon that increases the likelihood of embryo loss or birth defects in the offspring (Aitken et al. 2010b, Chandra et al. 2012). Oxidative stress is characterised as a state in which the rate of ROS generation exceeds the rate of its degradation within cells (Baumber et al. 2000). Once the cell has entered a state of oxidative stress, a cascade of detrimental events is initiated, commencing with loss of mitochondrial membrane potential and perturbation of the electron transport chain (ETC) and culminating in hydrogen abstraction from the polyunsaturated fatty acid (PUFA)-rich cell membrane and the generation of cytotoxic aldehydes (Koppers et al. 2008, Aitken et al. 2012a). Further downstream, oxidative stress may lead to the modification of both enzymatic and nonenzymatic antioxidants, leading to a loss of ability to neutralise free radicals by the sperm cell (Mohanty et al. 2016). Therefore, any minor increase in oxidative stress experienced by spermatozoa may proliferate rapidly and result in detrimental damage to sperm motility, viability and fertility (Aitken et al. 2012a, Aitken 2018).
The vulnerability of spermatozoa to oxidative attack stems from their ability to generate ROS, their lack of antioxidant protection and the abundance of substrates for oxidative attack including PUFA, proteins and DNA (Jones \& Stewart 1979, Aitken et al. 2010a, Shiva et al. 2011). Indeed, oxidative stress is now considered to be a major contributing factor in virtually all disease processes, including infertility (Dalle-Donne et al. 2003).

The evolutionary pressures arising from the horse's social structure, behavioural breeding strategy and environment are likely to be the driving force for such a high reliance of stallion spermatozoa on OXPHOS. In the natural breeding system, horses typically form a harem where one stallion protects and breeds with several mares. Stallions have therefore evolved to be sensitive detectors of oestrus and will breed quickly and efficiently, close to the time of ovulation. Since mating and ovulation are naturally well synchronised in this species, evolutionary pressure to extend sperm survival appears to have been minimal. Furthermore, where sperm competition (i.e. postcopulatory sexual selection) might occur, there is expected to be significant evolutionary pressure to increase sperm velocity. In comparing sperm parameters of 18 species of muroid rodents, Tourmente et al. (2015a) found that those species exhibiting competitive breeding strategies produce faster swimming spermatozoa and higher sperm ATP content (Tourmente et al. 2015a). This was later demonstrated to be attributed to a greater reliance on OXPHOS versus glycolytic pathways and is likely an adaptation to differing levels of sperm competition (Tourmente et al. 2015b). Although horses are not strictly considered polyandrous, it is not uncommon for mares to be bred by non-dominant stallions, while avoiding detection by the harem's dominant stallion (McDonnell 2016). Mares have also been reported to breed with multiple stallions, possibly to confuse paternity, thus avoiding infanticide by a stallion believing the foal to be another stallion's offspring (Bartoš et al. 2018). These behaviours are expected to facilitate postcopulatory sperm competition and contributed to the evolution of fast swimming, OXPHOS-reliant spermatozoa that efficiently produce high levels of ATP enabling them to rapidly reach and fertilise the oocyte.

\section{Lipid membrane peroxidation}

The sperm plasma membrane is made up of both saturated fatty acids (FA) and long-chain PUFAs, which are the initial targets of ROS attack. Stallion spermatozoa have a high ratio of PUFA to saturated FA, and this ratio further increases during the breeding season (Aurich et al. 2018). Docosapentaenoic acid (DPA), which is the predominant fatty acid in equine spermatozoa (Parks \& Lynch 1992), has also been shown to increase from the non-breeding to breeding season, causing a decrease in the overall omega 3:6 PUFA ratio (Aurich et al. 2018). 
The high concentration of PUFA contributes to high levels of fluidity and elasticity, both of which are necessary for sperm-egg fusion events and consequently, fertilisation (Hosnedlova et al. 2017, Aurich et al. 2018). However, this renders stallion spermatozoa more susceptible to lipid membrane peroxidation, particularly when combined with the high concentrations of ROS produced as a by-product of OXPHOS (Aitken \& Fisher 1994). Significant correlations between sperm ROS production and motility loss are largely explained by peroxidation of the lipid membrane, which leads to structural damage, changes in membrane fluidity and a loss of sperm function, including progressive motility and sperm-egg recognition (Aitken et al. 2010b, Gibb et al. 2014, Bromfield et al. 2015b, Kasperczyk et al. 2015, Hall et al. 2017). In addition, lipid peroxidation is associated with decreased sperm count, motility and percent morphologically normal cells in vivo and is one of the major contributors to oxidative and carbonyl stress (Shiva et al. 2011, Mohanty et al. 2016). Lipid peroxidation has been associated with numerous sperm deficiencies, and malondialdehyde (MDA), a marker of lipid peroxidation, has been reported as higher in the spermatozoa of oligozoospermic and azoospermic males, as well as asthenooospermic and teratozoospermic males when compared to their normozoospermic counterparts (Shiva et al. 2011). Lipid peroxidation also affects processes of sperm-oocyte fusion through premature acrosome damage (Gomez et al. 1998) and sperm-egg recognition (Bromfield et al. 2015b), which render the spermatozoa incapable of fertilising the oocyte (Töpfer-Petersen et al. 2005).

Cytotoxic aldehydes are generated following the removal of hydrogen atoms from PUFA during lipid peroxidation. Examples of these include acrolein, 4-hydroxynonenol (4HNE) and to a lesser extent MDA. Once generated, these cytotoxic aldehydes can further disrupt the ETC by covalently binding to exposed proteins, thereby disrupting their functionality. Examples of this include the disruption of ATP production by the adduction of $4 \mathrm{HNE}$ to succinate-coenzyme $\mathrm{Q}$ reductase (Aitken et al. 2012a, Moazamian et al. 2015) and the adduction of 4HNE to the heat shock protein HSPA2; an essential component of the HSPA2/ARSA/SPAM1 protein complex in both human and stallion spermatozoa (Bromfield et al. 2015b). This complex is necessary for sperm-egg recognition, and, as a consequence 4HNE adduction renders the sperm cell incapable of achieving fertilisation (Bromfield et al. 2015a,b).

Acrolein, one of the most reactive of aldehydes (Moazamian et al. 2015), may be formed as a consequence of PUFA peroxidative processes or during the oxidation of polyamine metabolites by cellular enzymes (Alarcon 1970, Hales 1982), which are present in high concentrations within the male reproductive tract. As such, acrolein plays a role in human subfertility
(Moazamian et al. 2015), but whether this is the case in the stallion is yet to be ascertained.

\section{Variation in fertility resulting from DNA damage}

Recent research into idiopathic infertility has revealed strong links between DNA damage and decreased fertility, early embryo loss and birth defects (Aitken et al. 2010b, Chandra et al. 2012). There are numerous factors which lead to DNA damage, but one common underlying factor is incomplete protamination which leads to poor compaction of DNA during spermatogenesis, thus leaving DNA vulnerable to assault during times of heat stress and oxidative attack (Moorefield et al. 2004, Aoki et al. 2006, Zhang et al. 2006, De luliis et al. 2009, Mohanty et al. 2016, Ketchum et al. 2018).

\section{DNA packaging}

During early spermatogenesis, histones and protamines function by binding and packaging nuclear DNA. Histone-bound DNA sequences are loosely compacted and so the histone-to-protamine transition is an essential process in achieving adequate condensation of sperm DNA. This involves extensive chromatin reorganisation and compaction, whereby histones are firstly removed and replaced by transitional proteins, which are consequently replaced by protamines (Ward \& Coffey 1991, Jha et al. 2017). In doing so, the DNA is more tightly compacted, allowing for streamlining of the sperm head, DNA stabilisation and crucially, protection of DNA from exogenous oxidative stressors (Aoki et al. 2006, Zhang et al. 2006, Ni et al. 2016). Any disruption to the composition of nuclear proteins will have profound effects on DNA integrity and therefore future fertilising potential and embryonic development (Szczygiel \& Ward 2002, Zhang et al. 2006). The abnormal expression of protamines (P1 or P2) leads to aberrant protamine ratios, which are, in turn, associated with defects in spermatogenesis and spermiogenesis leading to conditions such as oligozoospermia, asthenozoospermia or teratozoospermia, particularly in relation to head morphology and diminished sperm penetration assay scores (Aoki et al. 2006). Indeed, Netherton et al. (2017) reported a 3-fold increase of P2 in poor quality spermatozoa isolated using density gradient centrifugation. In the stallion, three protamine variants have been identified; protamine 1 St 1 and protamine 2 variants St2b and St2a (Pirhonen et al. 1989). Although the sequence of St2b and St2a are homologous, they differ in length and amino acid sequence which is thought to have result from gene duplication and successive point mutations (Pirhonen et al. 1989). However, since their discovery, no studies have yet indicated that stallion infertility is associated with aberrant protamine ratios. 
Levels of the precursor protamine 'pre-P2' found in the maturing spermatozoon influences the P1/P2 ratio, with higher pre-P2 levels indicative of a failure in the histoneto-protamine replacement process (Torregrosa et al. 2006). These protamine aberrations may be corrected through the use of in vitro manipulations. In men, even within sperm populations which are deemed protamine deficient upon global assessments, there are populations of cells present with normal protamine content which can be selected by density gradient centrifugation for use in assisted reproductive procedures such as IVF and ICSI (Aoki et al. 2006). However within the equine industry, conventional equine IVF attempts have been largely unsuccessful (Leemans et al. 2016), ICSI is both costly and not readily available on a commercial basis, while such technologies are not permitted by the thoroughbred industry.

\section{DNA under oxidative attack}

The onset of oxidative stress has been attributed as the root cause of a significant proportion of the sperm DNA damage (De luliis et al. 2009). DNA damage, when measured using the sperm chromatin structure assay (SCSA), has been shown to correlate with morphological defects and indeed fertility in the stallion along with other livestock species (Lopez-Fernandez et al. 2008, Morrell et al. 2008, Kumaresan et al. 2017). The decreased DNA integrity that may be identified using SCSA can be caused by multiple, independent factors stemming from events that occur during spermatogenesis (Torregrosa et al. 2006). There are numerous ways by which ROS can cause DNA damage including alteration of nitrogenous base pairs, modification to DNA crosslinks, induction of DNA fragmentation as a result of strand breaks, and finally chromosomal rearrangements (Kemal Duru et al. 2000). ROS have been identified as one of the main factors in the induction of DNA damage and therefore subfertility in stallions (Baumber et al. 2003). The vulnerability of defective sperm cells to oxidative attack has been highlighted with strong correlations evident between defective protamination or chromatin remodelling and spontaneous 8-hydroxy-2'-deoxyguanosine (8OHdG) formation (De luliis et al. 2009).

Strong correlations have been reported between nuclear $8 \mathrm{OHdG}$ formation, a major product of oxidative DNA damage and a known marker of oxidative stress, and chromatin remodelling (measured using CMA3), DNA fragmentation (measured by the TUNEL assay), mitochondrial superoxide levels and the loss of mitochondrial membrane potential (De luliis et al. 2009). Sperm mitochondria play a crucial role in the oxidative stress cascade, with unscavenged mitochondrial ROS leading to the release of cytochrome $\mathrm{C}$, resulting in caspase activation, apoptotic-like changes and cell death (Liu et al. 1996, De luliis et al. 2009). Furthermore, mitochondrial DNA is far more vulnerable to damage than nuclear DNA, so much so that some have postulated that the mitochondrial genome may provide a very sensitive early biomarker of ROS imbalance (Sawyer et al. 2003, Aitken et al. 2010a). Owing to the increased dependence on mitochondrial ATP production by stallion spermatozoa (Gibb et al. 2014), it is anticipated that the stallion sperm mitochondrial genome may in the future provide a robust marker of fertility for diagnostic and management purposes.

\section{Sperm proteins and their modifications as indicators of stallion fertility}

A proteome is the subset of proteins expressed within an organism, a cell type or a disease process (Thompson et al. 2016). In addition to the sperm cell proteome, a plethora of proteins are acquired by spermatozoa from accessory sex gland secretions and from the epididymis during maturation and ejaculation (Amaral et al. 2014). As protein-to-protein interactions are responsible for the vast majority of cellular functions, proteomic analyses provide both an insight into the effectiveness of spermiogenesis and also an understanding of the interaction between sperm molecular functions and fertility (Baker et al. 2007, Aitken \& Baker 2008, Oliva et al. 2009, Kwon et al. 2015a). The total protein content of the stallion ejaculate has been reported to range from 127 to $642 \mathrm{mg}$, while protein concentration ranges from 6.27 to $26.9 \mathrm{mg} / \mathrm{mL}$ (Novak et al. 2010). Swegen et al. (2015) identified over 1000 stallion sperm proteins, representing 975 genes. Of those, 372 proteins were involved in the cellular metabolic processes of fatty acid metabolism, glycolysis and OXPHOS, while 20 proteins were involved in defensive responses to oxidative damage. These include ROS scavengers superoxide dismutase and glutathione peroxidase (Swegen et al. 2015); although widely documented as the most important sperm antioxidants in other species, one report has suggested that their activity is limited in equine spermatozoa (Baumber \& Ball 2005), with the most important antioxidants being the aldehyde dehydrogenase family of enzymes (Gibb et al. 2016).

\section{Differential protein expression}

In animal production systems, proteomic tools are being used to identify global protein biomarkers, and this approach has successfully facilitated the prediction of superior sires for use in selective breeding programmes in boars (Kwon et al. 2015b). In the equine industry, particularly the thoroughbred sector, the identification of proteomic biomarkers of fertility is under active investigation and is expected to facilitate the prediction of times of high and low fertility during the breeding season. This will allow the implementation of management strategies to maximise PCC rates and in turn, breeding efficiency. To date, several studies have 
identified fertility biomarker candidate proteins from the spermatozoa of mice, men, livestock production animals, and to a lesser extent, stallions (Baker et al. 2005, Novak et al. 2010, Park et al. 2012, Kwon et al. 2015a,b, Swegen et al. 2015, Netherton et al. 2017). Indeed, at the time of publication of this review, a PubMed search using the terms 'stallion', 'sperm' and 'proteome' produced only six publications.

The expression of a number of proteins have been both positively (the glycolytic enzyme enolase (1) and negatively (voltage-dependent anion channel 2 and ubiquinol-cytochrome-c reductase complex core protein 2; UQCRC2) associated with bull fertility (Gitlits et al. 2000, Park et al. 2012). VDAC2 is associated with metabolite transportation, signal transduction and capacitation-related tyrosine phosphorylation (Arcelay et al. 2008, Liu et al. 2009) and is believed to be downregulated by the mitochondrial trifunctional protein, HADHA, which has also been positively correlated with boar fertility (Kwon et al. 2015a). UQCRC2, a mitochondrial protein, has been associated with both oxidative stress and ROS production, with UQCRC2 deficiency shown to increase ROS generation (Aguilera-Aguirre et al. 2009). Owing to the susceptibility of stallion spermatozoa to oxidative attack, and their reliance on OXPHOS as opposed to glycolysis, it will be of interest to investigate the expression of both enolase 1 and UQCRC2 during times of high and low fertility.

Spermadhesins, a family of secretory proteins, are expressed primarily in the seminal plasma and following ejaculation become bound to the sperm surface. It is postulated that the heparin and carbohydrate-binding ability of these proteins facilitates sperm-oocyte fusion (Topfer-Petersen et al. 1998, Töpfer-Petersen et al. 2005) and as such they have been the focus of numerous studies. Spermadhesins are abundant in the ejaculates of boars, whereas the diversity and expression of these proteins are greatly reduced in other species such as cattle, horses and humans (Töpfer-Petersen et al. 2005). Despite this, the similarity in the amino acid sequences of boar, bull and stallion spermadhesins can range from $40 \%$ up to $98 \%$ (Topfer-Petersen et al. 1998). The fertility status of production animals has been linked to the expression of such proteins in numerous studies, with spermadhesin Z13 (SPADH2) differentially expressed in the spermatozoa of fertile, subfertile and infertile bulls (Somashekar et al. 2017). While the exact mechanism by which SPADH2 affects fertility is yet to be elucidated, spermadhesins AQN-3 and AWN have been associated with litter size in boars (Kwon et al. 2015b, Somashekar et al. 2017), and as the amino acid sequence of stallion spermadhesin protein HSP-7 shares 98\% similarity with boar AWN (Reinert et al. 1996, 1997), it is conceivable that they share a common underlying function (Sanz et al. 1992, Reinert et al. 1997). Equine HSP-7 is a carbohydrate-binding protein and functions in the zona-binding interaction (Reinert et al. 1996); therefore, the expression of this protein may be another possible marker of fertility in stallions, warranting further investigation.

Positive associations between seminal plasma IGF1 concentrations and stallion fertility have also been reported (Macpherson et al. 2002, Novak et al. 2010). Novak et al. (2010) proposed the measurement of total ejaculate IGF1 content could be the most simple and effective measure of stallion fertility. This is a useful predictor in the area of artificial insemination, but its use in the natural breeding scenario is confounded by the fact that this calculation requires knowledge of both the IGF1 concentration (per $\mathrm{mL}$ ), as well as the total volume of the ejaculate; this is not known even if a postbreeding semen 'dismount sample' is collected as is often the case in the thoroughbred.

Seminal plasma proteins such as kallikrein-1E2, clusterin and specificity proteins SP1 and SP2 have been reported as being negatively associated with fertility, while both clusterin and SP1 are positively associated with ejaculate volume in stallions (Novak et al. 2010). SP1 and SP2 are part of the specificity protein (SP) family, functioning primarily in transcriptional regulation (Bouwman \& Philipsen 2002, Kolell \& Crawford 2002). SP shares a DNA-binding domain and are responsible for the expression of a wide variety of genes, particularly SP1 (Bouwman \& Philipsen 2002, Kolell \& Crawford 2002). Given that up to $25 \%$ of negative pregnancy diagnoses in horses may be attributable to early embryo death (Ball et al. 1989), this family of proteins are of particular interest, as murine studies have demonstrated that SP1 and SP2 are essential for normal embryonic development (Bouwman \& Philipsen 2002, Baur et al. 2010).

Clusterin is a chaperone-like protein involved in protein-to-protein reactions, lipid exchange and membrane remodelling during maturation (Law \& Griswold 1994, Griffiths et al. 2009). Interestingly, in bulls an inverse relationship was reported between sperm clusterin content and non-return rates, conception rates and sperm motility, while a positive relationship with percentage morphological abnormalities (Ibrahim et al. 2000). Similarly, expression of the clusterin gene was significantly increased in the semen samples of infertile men, compared to fertile cohorts, as reported by Zalata et al. (2012). In stallions, clusterin is the second most abundant protein secreted by the epididymis, indicating the importance of its role during epididymal maturation (Fouchecourt et al. 2000). However, there is a paucity of literature focused on elucidating the exact role of clusterin within the stallion ejaculates; therefore, its effect on sperm functionality remains unknown.

The sperm proteins malate dehydrogenase $(\mathrm{MDH})$, fumarate hydratase, citrate synthase, $\alpha$-enolase and dihydrolipoamide dehydrogenase are positively associated with first cycle conception rate in stallions (Novak et al. 2010). As first cycle conception rate is deemed to be a good indicator of relative fertility, it is 
believed that such proteins could be used as biomarkers or predictors of fertility. $\mathrm{MDH}$, fumarate hydratase and citrate synthase are enzymes involved in carbohydrate metabolism. Although stallion spermatozoa predominantly rely on OXPHOS for motility, carbohydrate metabolism may have uncharacterised roles in sperm function or survival. Indeed, improved carbohydrate metabolism may facilitate the increased use of glycolysis. Incubation of stallion spermatozoa with rosiglitazone, an antidiabetic compound, seems to increase their use of glycolysis, resulting in a decreased reliance on OXPHOS pathways, and thereby reducing ROS production and increasing longevity (Swegen et al. 2016).

Calmodulin (CALM1) has been identified as a possible biomarker of high fertility in boars (Kwon et al. 2015b) and bulls (Somashekar et al. 2017). CALM1 is an intermediate calcium-binding messenger protein, which interacts with ten key proteins including those involved in the regulation of calcium $\left(\mathrm{Ca}^{2+}\right)$, mediation of the centrosome, protein kinases and cytokinases (Somashekar et al. 2017). $\mathrm{Ca}^{2+}$ is one of the most important ions in the maintenance of sperm cell function. $\mathrm{Ca}^{2+}$ is particularly important in motility as a rise in $\mathrm{Ca}^{2+}$ stimulates the $\mathrm{Ca}^{2+}$ sensory proteins calaxins, which in turn inhibit dynein activity in the cell axoneme causing high amplitude asymmetric flagellar hyperactivation (Ho et al. 2002, Shiba et al. 2008, Mizuno et al. 2009, 2012). Furthermore, $\mathrm{Ca}^{2+}$ ions trigger the acrosome reaction, thereby enabling oocyte penetration and fertilisation (Yanagimachi 1970, Hong et al. 1984, Publicover et al. 2007, Kasperczyk et al. 2015). In stallion spermatozoa CALM1 is localised to the acrosome and flagellar principal piece and is involved in the regulation of sperm motility, the onset of tyrosine phosphorylation and thus capacitation (Gonzalez-Fernandez et al. 2012, Lasko et al. 2012), while in bulls, the under-expression of CALM1 was associated with the spermatozoa of subfertile and infertile bulls (Somashekar et al. 2017). Therefore, it would be expected that any change in the expression of this protein would result in fluctuations in fertility, but this hypothesis is yet to be confirmed.

Angiotensin-converting enzyme (ACE) has been identified in the testes and seminal plasma, with particularly high concentrations identified in the plasma membrane of ejaculated stallion spermatozoa (Ball et al. 2003). ACE is a dipeptidylcarboxypeptidase and while the specific role of ACE in sperm function is yet to be elucidated, it is thought that ACE functions in capacitation and acrosome reaction (Sabeur et al. 2000, Ball et al. 2003). Testis Ace knockout mice experience a high rate of fertilisation failure, with a significant reduction in both oviductal sperm transit and zona binding (Hagaman et al. 1998). In stallions, the haplotype of the $A C E$ gene significantly influences both the paternal and embryonic contribution to pregnancy, measured by PCC rates (Giesecke et al. 2011). ACE may prove as a valuable marker of fertility; however, further research is required to determine the exact mechanism by which ACE affects sperm function and to investigate its expression, along with the expression of other proteins discussed earlier, during times of high and low fertility. Figure 1 illustrates the journey of the spermatozoon from cell generation to fertilisation, highlighting the molecular pathways and signalling proteins associated with sperm maturation, ejaculation and fertilitsation.

While it is unlikely that a single protein can serve as a biomarker for subfertility of all aetiologies, further work is expected to reveal a series of reliable correlations between specific proteins and conception rates; these can then be developed into a robust multi-biomarker diagnostic platform for the early detection of stallion subfertility.

\section{Post-translational modifications}

The high level of moleclular diversity exhibited by the proteome is determined by numerous factors including the post-translational modification (PTM) of proteins (Samanta et al. 2016). As the spermatozoon has a reduced ability to synthesise proteins, the primary method in which functionality is acquired is via PTMs (Blaquier et al. 1988, Ross et al. 1990). The latter chemically alters protein properties by covalent processing events, such as the addition of modified groups to amino acid side chains or by proteolytic cleavage, and are generally catalysed by substrate-specific enzymes (Mann \& Jensen 2003, Samanta et al. 2016). These enzymes regulate the distribution, stability and function of proteins (Samanta et al. 2016). Epididymal maturation processes are essential for the creation of functional sperm cells (Baker et al. 2005). In the stallion, Fouchecourt et al. (2000) reported that at least 117 proteins are secreted into the epididymal lumen, many of which are capable of inducing the PTM of sperm proteins. Protein activity state, turnover, localisation and protein-to-protein interactions are governed by PTMs; therefore, the importance of such processes cannot be underestimated (Mann \& Jensen 2003). Table 1 illustrates the functional significance of different types of PTMs for normal cell metabolism: for example, phosphorylation is important for cell signalling while methylation is required for the regulation of gene expression.

Oxidative stress leads to the incorrect folding or cleavage of proteins, conformational changes to protein structure and folding, protein carbonylation and failure of vital processes such as phosphorylation and glycosylation. Under normal conditions, phosphorylation involves the alteration of protein structures via the introduction of covalently bound phosphate groups to the polypeptide chain (Samanta et al. 2016). It is one of the major PTMs responsible for important sperm functions, from maturation through to the acrosomal reaction and fertilisation 


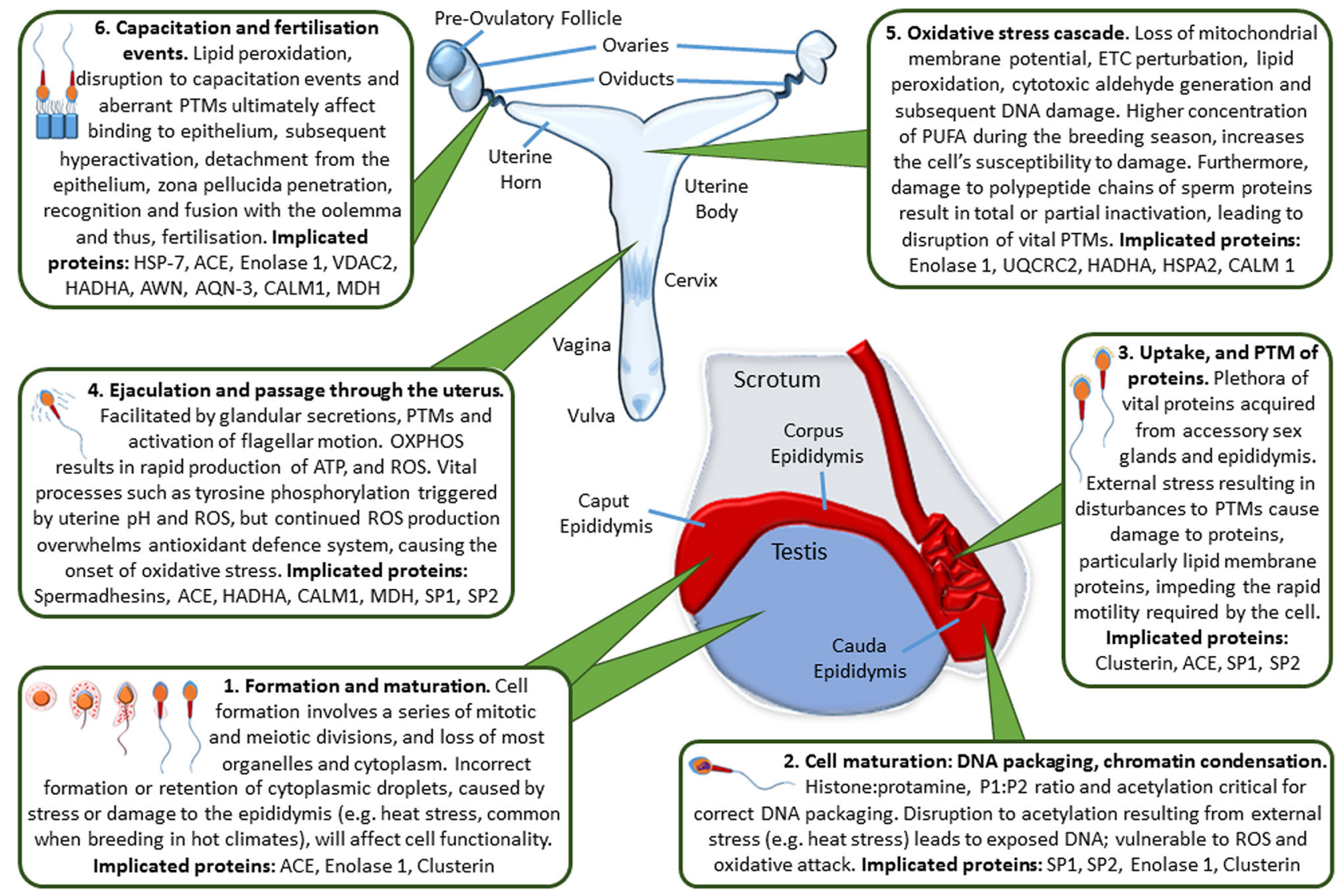

Figure 1 Journey of the equine spermatozoon from cell generation through to fertilisation; the effects of disruptions to cell processes, and the proteins implicated in each stage of development, involving function, signalling and stages when most vulnerable to damage.

(Sakkas et al. 2003). A series of in vitro and in vivo experiments carried out by Gonzalez-Fernandez et al. (2012) have revealed that the onset of tyrosine phosphorylation in stallion spermatozoa is governed primarily by $\mathrm{pH}$. The lower $\mathrm{pH}$, together with the $\mathrm{Ca}^{2+}$ content of stallion semen, prevents the onset of phosphorylation. However, once within the uterine lumen, which is at a higher $\mathrm{pH}$, a series of biochemical events unfold resulting in the onset of tyrosine phosphorylation and capacitation. The same conclusion has also been reached for human spermatozoa (Aitken et al. 1998).
The process of acetylation is critical for correct DNA packaging and chromatin condensation. Ketchum et al. (2018) have recently published that the histone H4 lysine acetylation event, H4K16ac, is the key marker in initiating the transition of nucleoproteins from histone-to-protamine structures in stallion spermatozoa. Conversely, protein carbonylation is not presently known to have beneficial roles in sperm functionality. This PTM is mediated by ROS, involving the oxidation of proteins, and is therefore negatively associated with sperm quality (Suzuki et al. 2010, Shiva et al. 2011). Oxidative stress can cause total or partial inactivation

Table 1 Functions of select post-translational modifications (adapted from (Mann \& Jensen (2003)).

\begin{tabular}{ll}
\hline PTM type & Functions \\
\hline Phosphorylation & Activation and inactivation of enzyme activity, modulation of molecular interaction, signalling \\
Acetylation & Protein stability, protection of N terminus, regulation of protein-DNA interactions \\
Acylation (fatty acid modification) & Cellular localisation and targeting signals, membrane tethering, mediator of protein-protein reactions \\
Methylation & Regulation of gene expression \\
Glycosylation & Excreted proteins, cell-cell recognition/signalling \\
GPI Anchor & Membrane tethering of enzymes and receptors \\
Hydroxyproline & Protein stabilisation and protein-ligand interactions \\
Disulphide Bond Formation & Intra- and intermolecular crosslink, protein stability \\
Ubiquitination & Destruction signal \\
\hline
\end{tabular}

PTM, post-translational modifications. 
of proteins as a consequence of conformational changes or damage to the polypeptide chain (Mohanty et al. 2016). Monitoring PTMs may provide useful information pertinent to fertility; however, no studies have focused on the mechanisms by which aberrant PTMs affect fertility in stallions and whether or not they can be used as biomarkers of fertility.

Lipid peroxidation together with protein carbonylation has been indicated as a biomarker for fertility, with the model reported by Mohanty et al. (2016) predicting the fertility status of fertile men versus recurrent pregnancy loss sufferers with $97 \%$ accuracy. As previously discussed, stallion spermatozoa produce high levels of ROS owing to their use of the OXPHOS pathway, and therefore, are predisposed to oxidative stress affecting lipids, proteins and DNA. The root cause and indeed full effects of aberrant PTM on sperm functionality and overall fertility have not yet been examined. Investigation into these mechanisms and the failure of normal protein function will provide pathways to elucidating how management regimens can affect stallion fertility, leading to enhanced production systems. Table 2 illustrates the most important diagnostic tools employed for investigating and predicting stallion fertility, along with the advantages and disadvantages of each assessment type.

\section{Role of RNA species in stallion sperm function}

The spermatozoon was previously described as being transcriptionally and translationally silent; however, new research has provided compelling evidence for the presence of sperm RNAs within the cell (Das et al. 2013, Ing et al. 2014). Ostermeier et al. (2002) conducted one of the first studies to reveal the presence of several thousand messenger RNAs (mRNA) in human spermatozoa. Since then there has been extensive research focused on the sperm transcriptome in livestock animals and to a lesser extent in stallions (Das et al. 2013, Jevsinek Skok et al. 2013, Ing et al. 2014). Originally it was believed that sperm RNAs were simply residues of spermatogenesis and served no function in cellular processes (Das et al. 2013). Studies have since demonstrated that mRNAs such as clusterin, PRM1 and PRM2 mRNA are delivered to the oocyte by spermatozoa upon fertilisation, thus contributing to zygotic and early embryonic development (Kempisty et al. 2008). Yuan et al. (2016) demonstrated that embryos generated from the sperm of Dicer conditional knockout mice had defective development to blastocyst stage; however, such defects were rescued following injection with purified sperm RNAs. In stallions, the use of sperm transcriptome analysis is now being investigated as a method of fertility biomarker discovery, and as a diagnostic tool for fertility assessments (Das et al. 2013).

A number of RNA species, including mRNA, IncRNA, rRNA and miRNA, have been characterised in stallion spermatozoa (Das et al. 2013, Ing et al. 2018). Approximately 11,500 gene transcripts have been detected in the stallion testes (Coleman et al. 2010, Das et al. 2013); 6500 of these are also present in stallion sperm, a ratio similar to that previously reported in men (Ostermeier et al. 2002). Of these, 60 transcripts are upregulated in spermatozoa compared to testes,

Table 2 Diagnostic tools for the investigation and prediction of stallion fertility.

\begin{tabular}{|c|c|c|}
\hline Assessment & Advantages & Disadvantages \\
\hline $\begin{array}{l}\text { DNA damage: sperm chromatin } \\
\text { dispersion }\end{array}$ & $\begin{array}{l}\text { - Simple and inexpensive } \\
\text { - High repeatability and accuracy } \\
\text { - Strong correlation with SCSA and TUNEL assays }\end{array}$ & $\begin{array}{l}\text { - Initial investigations reported no correlation with } \\
\text { pregnancy outcome } \\
\text { - Use in stallion fertility assessments yet to be } \\
\text { investigated }\end{array}$ \\
\hline $\begin{array}{l}\text { DNA damage: sperm chromatin } \\
\text { structure assay (SCSA) }\end{array}$ & $\begin{array}{l}\text { - Low intra- and inter-laboratory variation; robust } \\
\text { DFI assay } \\
\text { - Predictor of pregnancy success and fertility in } \\
\text { other species } \\
\text { - Correlations reported between stallion fertility } \\
\text { and SCSA }\end{array}$ & $\begin{array}{l}\text { - Flow cytometry required } \\
\text { - Proficiency of SCSA uncovering full extent of } \\
\text { DNA damage questioned } \\
\text { - Reliability as a predictor of stallion fertility } \\
\text { fluctuations yet to be investigated }\end{array}$ \\
\hline Oxidative DNA Damage: $8 \mathrm{OHdG}$ & $\begin{array}{l}\text { - } 8 \text { OHdG identified as an early biomarker of } \\
\text { oxidative damage } \\
\text { - } 8 \text {-OHdG negatively correlated with fertility, and } \\
\text { sperm quality in humans }\end{array}$ & $\begin{array}{l}\text { - Flow cytometry required } \\
\text { - Several methods and commercial kits available; } \\
\text { variable results } \\
\text { - Few reports implicating a relationship with } \\
\text { stallion fertility }\end{array}$ \\
\hline Morphological assessment & $\begin{array}{l}\text { - } \quad \text { Simple and inexpensive } \\
\text { - Correlations reported between percent } \\
\text { morphologically normal spermatozoa and } \\
\text { stallion PCC rates } \\
\text { - Inferred as an indicator of DFI }\end{array}$ & $\begin{array}{l}\text { - Analysis is subjective } \\
\text { mow studies investigating predictive value of } \\
\text { fluctuations }\end{array}$ \\
\hline Proteomic assessments & $\begin{array}{l}\text { - Provides insights into protein-to-protein } \\
\text { interactions and effectiveness of spermiogenesis } \\
\text { - Highly reliable in identification of biomarkers of } \\
\text { fertility } \\
\text { - Used in the prediction of superior sires in boar } \\
\text { breeding programmes }\end{array}$ & $\begin{array}{l}\text { - Costly and equipment not always readily } \\
\text { available } \\
\text { - No research carried out thus far into the } \\
\text { differential expression of proteins during times of } \\
\text { high and subfertility in stallions }\end{array}$ \\
\hline
\end{tabular}


while 165 transcripts have been detected in the sperm cell only, and pertain to genes involved in processes of ion, nucleotide and chromatin binding (Das et al. 2013). Therefore, stallion sperm mRNAs are not simply a remnant of the spermatozoon's past life as a diploid cell, but play active roles in sperm-egg interactions, fertilisation and early embryonic development (Das et al. 2013). Initial research into the use of mRNA as biomarkers of fertility has revealed four mRNAs (CATSPER1, OAZ3, aromatase (CYP13A1) and oestrogen receptor ESR1) which are lower in concentration in high quality spermatozoa when compared to low-quality sperm populations (Ing et al. 2014).

Spermatozoa were originally thought to be rRNA depleted (Ostermeier et al. 2002); however, studies have since proven the contrary in stallion spermatozoa (Das et al. 2013). During spermiogenesis, full-length rRNAs are degraded via selective cleavage in order to ensure translational arrest and thus prevent the synthesis of false proteins (Das et al. 2013).

Preliminary findings from Ing et al. (2018) have uncovered over 11,000 unique IncRNAs; 166 of which are differentially expressed between low and highquality stallion spermatozoa. Ing et al. (2018) also identified 159 mature miRNA sequences; eight of which are elevated in high-quality spermatozoa. Although only preliminary findings, such numbers of RNA species are almost double those previously identified by Das et al. (2013). MiRNA are short non-coding RNAs and function in the post-transcriptional regulation of mRNA by destabilising or supressing translation, thus impeding protein production (Jevsinek Skok et al. 2013, Schrimpf et al. 2014). Research into sperm miRNA expression in mice revealed that the miRNA cluster, MiR-880, plays a significant role in early embryonic development and gene regulation, as embryos generated using testicular and cauda sperm populations, which carry abundant MiR-880, developed normally, while embryos generated using sperm isolated from the caput epididymis, which are deficient in miR-880, failed soon after implantation (Conine et al. 2018). Das et al. (2013) previously identified three stallion sperm miRNAs (MIR34B, MIR34C and MIR449A) as being critical for gene expression and early embryonic development. MiRNAs are also potentially involved in the regulation of steroid synthesis during spermatogenesis, as these molecules have been indicated to function in the regulation of both Leydig and Sertoli cells in stallions (Schrimpf et al. 2014). Recently, Tsatsanis et al. (2015) identified miR-155 as marker of subfertility in men; therefore, it is conceivable that sperm miRNA expression may be developed in the future as a diagnostic tool reflective of sperm fertilisation capacity. However, such research, especially with regard to the stallion is in its early stages, and further research is required to elucidate the exact functions and roles of such non-coding RNAs in stallion subfertility.
Single nucleotide polymorphisms (SNPs) can affect the maturation, function, structure or expression levels of miRNAs (Mishra et al. 2008). Any disruption to miRNA function will have further downstream effects at the gene expression level. Schrimpf et al. (2014) identified three SNPs that significantly affect the estimated paternal contribution to pregnancy rates in Warmblood stallions. Authors proposed that the expression level of phospholipase C zeta 1 (PLCz1), a stallion fertility locus, may be affected when the miRNA motif is removed by such SNPs. Meanwhile Jevsinek Skok et al. (2013) reported that miRNA polymorphisms have a profound effect on a wide range of phenotypic traits in livestock animals, including that of the horse. However, at the time of this study, only one miRNA polymorphism was identified within the horse genome, in comparison to 125 in cattle and 92 in chicken, which authors attribute to a lag in equine genomic focused research, rather than a lack of genetic variability (Jevsinek Skok et al. 2013).

The role of sperm RNAs, particularly miRNA and IncRNA are still somewhat undetermined. However, new research is continuously emerging, demonstrating that such RNAs are essential for sperm function, fertilisation and early embryo development. Furthermore, research has also focused on the differential expression of RNAs, recently Jiang et al. (2016) reported over 7700 IncRNAs and over 6000 mRNAs which were differentially expressed between the sperm of diabetic mice and controls. Authors revealed through GO and pathway analysis that the functions of such mRNAs were closely associated with many spermatogenic processes such as OXPHOS, glucose metabolism and lipid metabolism (Jiang et al. 2016). These findings are extremely relevant and may prove useful in the stallion to determine the link between fertilising potential, fertility fluctuations and RNA expression.

\section{Conclusion}

Deciphering the metabolic strategies employed by stallion spermatozoa has heralded the ability to use ROS production, antioxidant capacity and DNA damage measurements as markers of sperm quality, predictors of fertility fluctuations and indeed, diagnostic techniques for the investigation of stallion subfertility. There has been increased focus on the use of proteomic tools in fertility biomarker discovery, with several sperm biomarker proteins identified in livestock species; yet, stallion sperm proteomic studies thus far have been largely descriptive in nature. Large-scale, quantitative analyses targeting the full proteome are needed in order to develop truly useful biomarker panels which are relevant across the breeding industry.

Even less well studied are the roles of RNA species in stallion sperm function. Future research must focus on elucidating the link between sperm RNA species and fertility, and in particular, whether non-coding 
RNAs participate in the spermatozoon's acquisition of fertilising capacity or contribute significantly to embryo development. Such studies will potentially provide additional means for predicting the breeding prospects of stallions, which will be crucially important for planning the breeding 'careers', along with optimal welfare outcomes of these animals. The equine breeding industry, with its accurate recording of PCC rates and closely managed breeding systems, provides an excellent opportunity for meaningful and thorough investigation of the roles of emerging molecular mechanisms in sperm function and fertility.

\section{Declaration of interest}

Laureate Professor John Aitken is a member of the editorial board of Reproduction. The other authors have nothing to disclose.

\section{Funding}

This work was supported by the Australian Research Council in conjunction with the following partner organisations under Linkage Grant LP160100824: the Hunter Valley Equine Research Council, Memphasys Ltd, Texas A\&M University, the University of Sydney, EquiBreed NZ Ltd, CellOxess, Harness Racing Australia and Scone Equine Hospital.

\section{Author contribution statement}

A Swegen and Z Gibb: co-senior authors.

\section{References}

Aguilera-Aguirre L, Bacsi A, Saavedra-Molina A, Kurosky A, Sur S \& Boldogh I 2009 Mitochondrial dysfunction increases allergic airway inflammation. Journal of Immunology 183 5379-5387. (https://doi. org/10.4049/jimmunol.0900228)

Aitken RJ 2018 Not every sperm is sacred; a perspective on male infertility. Molecular Human Reproduction 24 287-298. (https://doi.org/10.1093/ molehr/gay010)

Aitken RJ \& Baker MA 2008 The role of proteomics in understanding sperm cell biology. International Journal of Andrology 31 295-302. (https://doi. org/10.1111/j.1365-2605.2007.00851.x)

Aitken J \& Fisher H 1994 Reactive oxygen species generation and human spermatozoa: the balance of benefit and risk. BioEssays 16 259-267. (https://doi.org/10.1002/bies.950160409)

Aitken RJ, Harkiss D, Knox W, Paterson M \& Irvine S 1998 On the cellular mechanisms by which the bicarbonate ion mediates the extragenomic action of progesterone on human spermatozoa. Biology of Reproduction 58 186-196. (https://doi.org/10.1095/biolreprod58.1.186)

Aitken RJ, Baker MA, De luliis GN \& Nixon B 2010a New insights into sperm physiology and pathology. Handbook of Experimental Pharmacology 198 99-115. (https://doi.org/10.1007/978-3-642-02062-9_7)

Aitken RJ, De Iuliis GN, Finnie JM, Hedges A \& Mclachlan RI $2010 b$ Analysis of the relationships between oxidative stress, DNA damage and sperm vitality in a patient population: development of diagnostic criteria. Human Reproduction 25 2415-2426. (https://doi.org/10.1093/ humrep/deq214)

Aitken RJ, Gibb Z, Mitchell LA, Lambourne SR, Connaughton HS \& De Iuliis GN 2012a Sperm motility is lost in vitro as a consequence of mitochondrial free radical production and the generation of electrophilic aldehydes but can be significantly rescued by the presence of nucleophilic thiols. Biology of Reproduction 87 110. (https://doi. org/10.1095/biolreprod.112.102020)

Aitken RJ, Jones KT \& Robertson SA 2012b Reactive oxygen species and sperm function - in sickness and in health. Journal of Andrology 33 1096-1106. (https://doi.org/10.2164/ jandrol.112.016535)

Alarcon RA 1970 Acrolein. IV. Evidence for the formation of the cytotoxic aldehyde acrolein from enzymatically oxidized spermine or spermidine. Archives of Biochemistry and Biophysics 137 365-372. (https://doi. org/10.1016/0003-9861(70)90450-9)

Amaral A, Castillo J, Ramalho-Santos J \& Oliva R 2014 The combined human sperm proteome: cellular pathways and implications for basic and clinical science. Human Reproduction Update 20 40-62. (https:// doi.org/10.1093/humupd/dmt046)

Aoki VW, Emery BR, Liu L \& Carrell DT 2006 Protamine levels vary between individual sperm cells of infertile human males and correlate with viability and DNA integrity. Journal of Andrology 27 890-898. (https://doi.org/10.2164/jandrol.106.000703)

Arcelay E, Salicioni AM, Wertheimer E \& Visconti PE 2008. Identification of proteins undergoing tyrosine phosphorylation during mouse sperm capacitation. International Journal of Developmental Biology $\mathbf{5 2}$ 463-472. (https://doi.org/ 10.1387/ijdb.072555ea)

Aurich C, Ortega Ferrusola C, Peña Vega FJ, Schrammel N, Morcuende D \& Aurich J 2018 Seasonal changes in the sperm fatty acid composition of Shetland Pony stallions. Theriogenology 107 149-153. (https://doi. org/10.1016/j.theriogenology.2017.11.004)

Baker MA, Witherdin R, Hetherington L, Cunningham-Smith K \& Aitken RJ 2005 Identification of post-translational modifications that occur during sperm maturation using difference in two-dimensional gel electrophoresis. Proteomics 5 1003-1012. (https://doi.org/10.1002/ pmic.200401100)

Baker MA, Reeves G, Hetherington L, Muller J, Baur I \& Aitken RJ 2007 Identification of gene products present in Triton X-100 soluble and insoluble fractions of human spermatozoa lysates using LC-MS/ MS analysis. Proteomics: Clinical Applications 1 524-532. (https://doi. org/10.1002/prca.200601013)

Ball BA, Little TV, Weber JA \& Woods GL 1989 Survival of day-4 embryos from young, normal mares and aged, subfertile mares after transfer to normal recipient mares. Journal of Reproduction and Fertility 85 187-194. (https://doi.org/10.1530/jrf.0.0850187)

Ball BA, Gravance CG, Wessel MT \& Sabeur K 2003 Activity of angiotensinconverting enzyme (ACE) in reproductive tissues of the stallion and effects of angiotensin II on sperm motility. Theriogenology 59 901-914. (https://doi.org/10.1016/S0093-691X(02)01127-5)

Bartoš L, Bartošová J \& Pluháček J 2018 Male-free environment prevents pregnancy disruption in domestic horse mares mated away of home. Applied Animal Behaviour Science 200 67-70. (https://doi.org/10.1016/j. applanim.2017.11.006)

Baumber J \& Ball BA 2005 Determination of glutathione peroxidase and superoxide dismutase-like activities in equine spermatozoa, seminal plasma, and reproductive tissues. American Journal of Veterinary Research 66 1415-1419. (https://doi.org/10.2460/ ajvr.2005.66.1415)

Baumber J, Ball BA, Gravance CG, Medina V \& Davies-Morel MC 2000 The effect of reactive oxygen species on equine sperm motility, viability, acrosomal integrity, mitochondrial membrane potential, and membrane lipid peroxidation. Journal of Andrology 21 895-902. (https://doi. org/10.1002/j.1939-4640.2000.tb03420.x)

Baumber J, Ball BA, Linfor JJ \& Meyers SA 2003 Reactive oxygen species and cryopreservation promote DNA fragmentation in equine spermatozoa. Journal of Andrology 24 621-628. (https://doi. org/10.1002/j.1939-4640.2003.tb02714.x)

Baur F, Nau K, Sadic D, Allweiss L, Elsässer HP, Gillemans N, De Wit T, Krüger I, Vollmer M, Philipsen S et al. 2010 Specificity protein 2 (Sp2) is essential for mouse development and autonomous proliferation of mouse embryonic fibroblasts. PLOS ONE 5 e9587. (https://doi.org/10.1371/ journal.pone.0009587)

Blaquier JA, Cameo MS, Cuasnicu PS, Gonzalez Echeverria MF, Pineiro L, Tezon JG \& Vazquez MH 1988 On the role of epididymal factors in sperm fertility. Reproduction, Nutrition, Developpement 28 1209-1216. (https://doi.org/10.1051/rnd:19880801) 
Bouwman P \& Philipsen S 2002 Regulation of the activity of Sp1-related transcription factors. Molecular and Cellular Endocrinology 195 27-38. (https://doi.org/10.1016/S0303-7207(02)00221-6)

Bromfield E, Aitken RJ \& Nixon B 2015a Novel characterization of the HSPA2-stabilizing protein BAG6 in human spermatozoa. Molecular Human Reproduction 21 755-769. (https://doi.org/10.1093/molehr/ gav041)

Bromfield EG, Aitken RJ, Anderson AL, Mclaughlin EA \& Nixon B 2015b The impact of oxidative stress on chaperone-mediated human spermegg interaction. Human Reproduction 30 2597-2613. (https://doi. org/10.1093/humrep/dev214)

Chandra S, Romero MJ, Shatanawi A, Alkilany AM, Caldwell RB \& Caldwell RW 2012 Oxidative species increase arginase activity in endothelial cells through the RhoA/Rho kinase pathway. British Journal of Pharmacology 165 506-519. (https://doi.org/10.1111/j.14765381.2011.01584.x)

Coleman SJ, Zeng Z, Wang K, Luo S, Khrebtukova I, Mienaltowski MJ, Schroth GP, Liu J \& Macleod JN 2010 Structural annotation of equine protein-coding genes determined by mRNA sequencing. Animal Genetics 41 (Supplement 2) 121-130. (https://doi.org/10.1111/j.13652052.2010.02118.x)

Conine CC, Sun F, Song L, Rivera-Pérez JA \& Rando OJ 2018 Small RNAs gained during epididymal transit of sperm are essential for embryonic development in mice. Developmental Cell 46 470.e3-480.e3. (https:// doi.org/10.1016/j.devcel.2018.06.024)

Dalle-Donne I, Rossi R, Giustarini D, Milzani A \& Colombo R 2003 Protein carbonyl groups as biomarkers of oxidative stress. Clinica Chimica Acta: International Journal of Clinical Chemistry 329 23-38. (https://doi. org/10.1016/S0009-8981(03)00003-2)

Das PJ, Mccarthy F, Vishnoi M, Paria N, Gresham C, Li G, Kachroo P, Sudderth AK, Teague S, Love CC et al. 2013 Stallion sperm transcriptome comprises functionally coherent coding and regulatory RNAs as revealed by microarray analysis and RNA-seq. PLOS ONE 8 e56535. (https://doi. org/10.1371/journal.pone.0056535)

De Iuliis GN, Thomson LK, Mitchell LA, Finnie JM, Koppers AJ, Hedges A, Nixon B \& Aitken RJ 2009 DNA damage in human spermatozoa is highly correlated with the efficiency of chromatin remodeling and the formation of 8-hydroxy-2'-deoxyguanosine, a marker of oxidative stress. Biology of Reproduction 81 517-524. (https://doi.org/10.1095/ biolreprod.109.076836)

Fouchecourt S, Metayer S, Locatelli A, Dacheux F \& Dacheux JL 2000 Stallion epididymal fluid proteome: qualitative and quantitative characterization; secretion and dynamic changes of major proteins. Biology of Reproduction 62 1790-1803. (https://doi.org/10.1095/ biolreprod62.6.1790)

Gibb Z, Lambourne SR \& Aitken RJ 2014 The paradoxical relationship between stallion fertility and oxidative stress. Biology of Reproduction 91 77. (https://doi.org/10.1095/biolreprod.114.118539)

Gibb Z, Lambourne SR, Curry BJ, Hall SE \& Aitken RJ 2016 Aldehyde dehydrogenase plays a pivotal role in the maintenance of stallion sperm motility. Biology of Reproduction 94 1-11. (https://doi.org/10.1095/ biolreprod.116.140509)

Giesecke K, Hamann H, Stock KF, Klewitz J, Martinsson G, Distl O \& Sieme H 2011 Evaluation of ACE, SP17, and FSHB as candidates for stallion fertility in Hanoverian Warmblood horses. Animal Reproduction Science 126 200-206. (https://doi.org/10.1016/j.anireprosci.2011.05.007)

Gitlits VM, Toh BH, Loveland KL \& Sentry JW 2000 The glycolytic enzyme enolase is present in sperm tail and displays nucleotide-dependent association with microtubules. European Journal of Cell Biology 79 104-111. (https://doi.org/10.1078/S0171-9335(04)70012-6)

Gomez E, Irvine DS \& Aitken RJ 1998 Evaluation of a spectrophotometric assay for the measurement of malondialdehyde and 4-hydroxyalkenals in human spermatozoa: relationships with semen quality and sperm function. International Journal of Andrology 21 81-94. (https://doi. org/10.1046/j.1365-2605.1998.00106.x)

Gonzalez-Fernandez L, Macias-Garcia B, Velez IC, Varner DD \& Hinrichs K 2012 Calcium-calmodulin and pH regulate protein tyrosine phosphorylation in stallion sperm. Reproduction 144 411-422. (https:// doi.org/10.1530/REP-12-0067)

Gramm M \& Marksteiner R 2010 The effect of age on thoroughbred racing performance. Journal of Equine Science 21 73-78. (https://doi. org/10.1294/jes.21.73)
Griffiths GS, Galileo DS, Aravindan RG \& Martin-Deleon PA 2009 Clusterin facilitates exchange of glycosyl phosphatidylinositol-linked SPAM1 between reproductive luminal fluids and mouse and human sperm membranes. Biology of Reproduction 81 562-570. (https://doi. org/10.1095/biolreprod.108.075739)

Hagaman JR, Moyer JS, Bachman ES, Sibony M, Magyar PL, Welch JE, Smithies O, Krege JH \& O'brien DA 1998 Angiotensin-converting enzyme and male fertility. PNAS 95 2552-2557. (https://doi.org/10.1073/ pnas.95.5.2552)

Hales BF 1982 Comparison of the mutagenicity and teratogenicity of cyclophosphamide and its active metabolites, 4-hydroxycyclophosphamide, phosphoramide mustard, and acrolein. Cancer Research 42 3016-3021.

Hall SE, Aitken RJ, Nixon B, Smith ND \& Gibb Z 2017 Electrophilic aldehyde products of lipid peroxidation selectively adduct to heat shock protein 90 and arylsulfatase $\mathrm{A}$ in stallion spermatozoa. Biology of Reproduction 96 107-121. (https://doi.org/10.1095/biolreprod.116.145292)

Ho HC, Granish KA \& Suarez SS 2002 Hyperactivated motility of bull sperm is triggered at the axoneme by $\mathrm{Ca} 2+$ and not cAMP. Developmental Biology 250 208-217. (https://doi.org/10.1006/dbio.2002.0797)

Hong CY, Chiang BN \& Turner P 1984 Calcium ion is the key regulator of human sperm function. Lancet 2 1449-1451. (https://doi.org/10.1016/ S0140-6736(84)91634-9)

Hosnedlova B, Kepinska M, Skalickova S, Fernandez C, RuttkayNedecky B, Malevu TD, Sochor J, Baron M, Melcova M, Zidkova J et al. 2017 A summary of new findings on the biological effects of selenium in selected animal species - a critical review. International Journal of Molecular Sciences 18 E2209. (https://doi.org/10.3390/ijms18102209)

Ibrahim NM, Gilbert GR, Loseth KJ \& Crabo BG 2000 Correlation between clusterin-positive spermatozoa determined by flow cytometry in bull semen and fertility. Journal of Andrology 21 887-894. (https://doi. org/10.1002/j.1939-4640.2000.tb03419.x)

Ing NH, Forrest DW, Love CC \& Varner DD 2014 Dense spermatozoa in stallion ejaculates contain lower concentrations of mRNAs encoding the sperm specific calcium channel 1, ornithine decarboxylase antizyme 3, aromatase, and estrogen receptor alpha than less dense spermatozoa. Theriogenology 82 347-353. (https://doi.org/10.1016/j. theriogenology.2014.04.016)

Ing NH, Konganti K, Ghaffari N, Johnson CD, Forrest DW, Love CC \& Varner DD 2018 Functional RNAs in stallion sperm: potential indicators of sperm quality and contributors to fertility. Journal of Equine Veterinary Science 66 31. (https://doi.org/10.1016/j.jevs.2018.05.011)

Jevsinek Skok D, Godnic I, Zorc M, Horvat S, Dovc P, Kovac M \& Kunej T 2013 Genome-wide in silico screening for microRNA genetic variability in livestock species. Animal Genetics 44 669-677. (https:// doi.org/10.1111/age.12072)

Jha KN, Tripurani SK \& Johnson GR 2017 Tssk6 is required for $\gamma \mathrm{H} 2 \mathrm{AX}$ formation and the histone-to-protamine transition during spermiogenesis. Journal of Cell Science 130 1835-1844. (https://doi.org/10.1242/ jcs.202721)

Jiang GJ, Zhang T, An T, Zhao DD, Yang XY, Zhang DW, Zhang Y, Mu QQ, Yu N, Ma XS et al. 2016 Differential expression of long noncoding RNAs between sperm samples from diabetic and nondiabetic mice. PLOS ONE 11 e0154028. (https://doi.org/10.1371/ journal.pone.0154028)

Jones RC \& Stewart DL 1979 The effects of cooling to 5 degrees C and freezing and thawing on the ultrastructure of bull spermatozoa. Journal of Reproduction and Fertility 56 233-238. (https://doi.org/10.1530/ jrf.0.0560233)

Kasperczyk A, Dobrakowski M, Horak S, Zalejska-Fiolka J \& Birkner E 2015 The influence of macro and trace elements on sperm quality. Journal of Trace Elements in Medicine and Biology 30 153-159. (https:// doi.org/10.1016/j.jtemb.2014.12.007)

Kemal Duru N, Morshedi M \& Oehninger S 2000 Effects of hydrogen peroxide on DNA and plasma membrane integrity of human spermatozoa. Fertility and Sterility 74 1200-1207. (https://doi.org/10.1016/S00150282(00)01591-0)

Kempisty B, Antosik P, Bukowska D, Jackowska M, Lianeri M, Jaskowski JM \& Jagodzinski PP 2008 Analysis of selected transcript levels in porcine spermatozoa, oocytes, zygotes and two-cell stage embryos. Reproduction, Fertility, and Development 20 513-518. (https://doi. org/10.1071/RD07211) 
Ketchum CC, Larsen CD, Mcneil A, Meyer-Ficca ML \& Meyer RG 2018 Early histone $\mathrm{H} 4$ acetylation during chromatin remodeling in equine spermatogenesis. Biology of Reproduction 98 115-129. (https://doi. org/10.1093/biolre/iox159)

Kolell KJ \& Crawford DL 2002 Evolution of sp transcription factors. Molecular Biology and Evolution 19 216-222. (https://doi.org/10.1093/ oxfordjournals.molbev.a004074)

Koppers AJ, De Iuliis GN, Finnie JM, Mclaughlin EA \& Aitken RJ 2008 Significance of mitochondrial reactive oxygen species in the generation of oxidative stress in spermatozoa. Journal of Clinical Endocrinology and Metabolism 93 3199-3207. (https://doi.org/10.1210/jc.2007-2616)

Kumaresan A, Johannisson A, Al-Essawe EM \& Morrell JM 2017 Sperm viability, reactive oxygen species, and DNA fragmentation index combined can discriminate between above- and below-average fertility bulls. Journal of Dairy Science 100 5824-5836. (https://doi.org/10.3168/ jds.2016-12484)

Kwon WS, Oh SA, Kim YJ, Rahman MS, Park YJ \& Pang MG 2015a Proteomic approaches for profiling negative fertility markers in inferior boar spermatozoa. Scientific Reports 5 13821. (https://doi.org/10.1038/ srep13821)

Kwon WS, Rahman MS, Lee JS, Yoon SJ, Park YJ \& Pang MG 2015b Discovery of predictive biomarkers for litter size in boar spermatozoa. Molecular and Cellular Proteomics 14 1230-1240. (https://doi. org/10.1074/mcp.M114.045369)

Lasko J, Schlingmann K, Klocke A, Mengel GA \& Turner R 2012 Calcium/ calmodulin and CAMP/protein kinase-A pathways regulate sperm motility in the stallion. Animal Reproduction Science 132 169-177. (https://doi.org/10.1016/j.anireprosci.2012.05.007)

Law GL \& Griswold MD 1994 Activity and form of sulfated glycoprotein 2 (clusterin) from cultured Sertoli cells, testis, and epididymis of the rat. Biology of Reproduction 50 669-679. (https://doi.org/10.1095/ biolreprod50.3.669)

Leemans B, Gadella BM, Stout TA, De Schauwer C, Nelis H, Hoogewijs M \& Van Soom A 2016 Why doesn't conventional IVF work in the horse? The equine oviduct as a microenvironment for capacitation/fertilization. Reproduction 152 R233-R245. (https://doi.org/10.1530/REP-16-0420)

Liu X, Kim CN, Yang J, Jemmerson R \& Wang X 1996 Induction of apoptotic program in cell-free extracts: requirement for dATP and cytochrome c. Cell 86 147-157. (https://doi.org/10.1016/S0092-8674(00)80085-9)

Liu B, Wang Z, Zhang W \& Wang X 2009. Expression and localization of voltage-dependent anion channels (VDAC) in human spermatozoa. Biochemical and Biophysical Research Communications 378 366-370. (https://doi.org/10.1016/j.bbrc.2008.10.177)

Lopez-Fernandez C, Perez-Llano B, Garcia-Casado P, Sala R, Gosalbez A, Arroyo F, Fernandez JL \& Gosalvez J 2008 Sperm DNA fragmentation in a random sample of the Spanish boar livestock. Animal Reproduction Science 103 87-98. (https://doi.org/10.1016/j.anireprosci.2006.11.015)

Macpherson ML, Simmen RC, Simmen FA, Hernandez J, Sheerin BR, Varner DD, Loomis P, Cadario ME, Miller CD, Brinsko SP et al. 2002 Insulin-like growth factor-I and insulin-like growth factor binding protein-2 and -5 in equine seminal plasma: association with sperm characteristics and fertility. Biology of Reproduction 67 648-654. (https://doi.org/10.1095/biolreprod67.2.648)

Mann M \& Jensen ON 2003 Proteomic analysis of post-translational modifications. Nature Biotechnology 21 255-261. (https://doi. org/10.1038/nbt0303-255)

McDonnell SM 2016 Revisiting clinical stallion sexual behavior: applying ethology in the breeding shed. Journal of Equine Veterinary Science $\mathbf{4 3}$ S18-S22. (https://doi.org/10.1016/j.jevs.2016.06.070)

Mishra PJ, Mishra PJ, Banerjee D \& Bertino JR 2008 MiRSNPs or MiRpolymorphisms, new players in microRNA mediated regulation of the cell: introducing microRNA pharmacogenomics. Cell Cycle 7 853-858. (https://doi.org/10.4161/cc.7.7.5666)

Mizuno K, Padma P, Konno A, Satouh Y, Ogawa K \& Inaba K 2009 A novel neuronal calcium sensor family protein, calaxin, is a potential $\mathrm{Ca}(2+)$-dependent regulator for the outer arm dynein of metazoan cilia and flagella. Biology of the Cell 101 91-103. (https://doi.org/10.1042/ BC20080032)

Mizuno K, Shiba K, Okai M, Takahashi Y, Shitaka Y, Oiwa K, Tanokura M \& Inaba K 2012 Calaxin drives sperm chemotaxis by $\mathrm{Ca}(2+)$-mediated direct modulation of a dynein motor. PNAS 109 20497-20502. (https:// doi.org/10.1073/pnas.1217018109)
Moazamian R, Polhemus A, Connaughton H, Fraser B, Whiting S, Gharagozloo P \& Aitken RJ 2015 Oxidative stress and human spermatozoa: diagnostic and functional significance of aldehydes generated as a result of lipid peroxidation. Molecular Human Reproduction 21 502-515. (https://doi.org/10.1093/molehr/gav014)

Mohanty G, Swain N, Goswami C, Kar S \& Samanta L 2016 Histone retention, protein carbonylation, and lipid peroxidation in spermatozoa: possible role in recurrent pregnancy loss. Systems Biology in Reproductive Medicine 62 201-212. (https://doi.org/10.3109/1939636 8.2016.1148798)

Moorefield KS, Fry SJ \& Horowitz JM 2004 Sp2 DNA binding activity and trans-activation are negatively regulated in mammalian cells. Journal of Biological Chemistry 279 13911-13924. (https://doi.org/10.1074/jbc. M313589200)

Morrell JM, Johannisson A, Dalin AM, Hammar L, Sandebert T \& Rodriguez-Martinez H 2008 Sperm morphology and chromatin integrity in Swedish Warmblood stallions and their relationship to pregnancy rates. Acta Veterinaria Scandinavica 50 2. (https://doi.org/10.1186/17510147-50-2)

Morris LHA \& Allen WR 2002 Reproductive efficiency of intensively managed Thoroughbred mares in Newmarket. Equine Veterinary Journal 34 51-60. (https://doi.org/10.2746/042516402776181222)

Nath LC, Anderson GA \& Mckinnon AO 2010 Reproductive efficiency of Thoroughbred and Standardbred horses in north-east Victoria. Australian Veterinary Journal $\mathbf{8 8}$ 169-175. (https://doi.org/10.1111/j.17510813.2010.00565.x)

Netherton JK, Hetherington L, Ogle RA, Velkov T \& Baker MA 2017 Proteomics analysis of good and poor quality human sperm demonstrates that several proteins are routinely aberrantly regulated. Biology of Reproduction 99 395-408. (doi:10.1093/biolre/iox166)

Ni K, Spiess AN, Schuppe HC \& Steger K 2016 The impact of sperm protamine deficiency and sperm DNA damage on human male fertility: a systematic review and meta-analysis. Andrology 4 789-799. (https:// doi.org/10.1111/andr.12216)

Novak S, Smith TA, Paradis F, Burwash L, Dyck MK, Foxcroft GR \& Dixon WT 2010 Biomarkers of in vivo fertility in sperm and seminal plasma of fertile stallions. Theriogenology 74 956-967. (https://doi. org/10.1016/j.theriogenology.2010.04.025)

Oki H, Sasaki Y \& Willham RL 1994 Genetics of racing performance in the Japanese Thoroughbred horse: II. Environmental variation of racing time on turf and dirt tracks and the influence of sex, age, and weight carried on racing time. Journal of Animal Breeding and Genetics 111 128-137. (https://doi.org/10.1111/j.1439-0388.1994. tb00446.x)

Oliva R, De Mateo S \& Estanyol JM 2009 Sperm cell proteomics. Proteomics 9 1004-1017. (https://doi.org/10.1002/pmic.200800588)

Ostermeier GC, Dix DJ, Miller D, Khatri P \& Krawetz SA 2002 Spermatozoal RNA profiles of normal fertile men. Lancet $360772-777$. (https://doi.org/10.1016/S0140-6736(02)09899-9)

Pagan JD, Koch A \& Caddel SE 2005 Size matters at the sales. In Advances in Equine Nutrition, vol. III, pp 433-437. Ed JD Pagan. Nottingham, UK: Nottingham University Press.

Park YJ, Kwon WS, Oh SA \& Pang MG 2012 Fertility-related proteomic profiling bull spermatozoa separated by Percoll. Journal of Proteome Research 11 4162-4168. (https://doi.org/10.1021/pr300248s)

Parks JE \& Lynch DV 1992 Lipid composition and thermotropic phase behavior of boar, bull, stallion, and rooster sperm membranes. $\begin{array}{llll}\text { Cryobiology } 29 & 255-266 . & \text { (https://doi.org/10.1016/0011- }\end{array}$ 2240(92)90024-V)

Parlevliet JM \& Colenbrander B 1999 Prediction of first season stallion fertility of 3-year-old Dutch Warmbloods with prebreeding assessment of percentage of morphologically normal live sperm. Equine Veterinary Journal $31 \quad 248-251 . \quad$ (https://doi.org/10.1111/j.2042-3306.1999. tb03181.x)

Petrunkina AM, Waberski D, Gunzel-Apel AR \& Topfer-Petersen E 2007 Determinants of sperm quality and fertility in domestic species. Reproduction 134 3-17. (https://doi.org/10.1530/REP-07-0046)

Pirhonen A, Linnala-Kankkunen A \& Maenpaa PH 1989 Comparison of partial amino acid sequences of two protamine 2 variants from stallion sperm. Structural evidence that the variants are products of different genes. FEBS Letters 244 199-202. (https://doi.org/10.1016/00145793(89)81192-5) 
Publicover S, Harper CV \& Barratt C 2007 [Ca2+]i signalling in sperm-making the most of what you've got. Nature Cell Biology 9 235-242. (https://doi.org/10.1038/ncb0307-235)

Reinert M, Calvete JJ, Sanz L, Mann K \& Topfer-Petersen E 1996 Primary structure of stallion seminal plasma protein HSP-7, a zonapellucida-binding protein of the spermadhesin family. European Journal of Biochemistry 242 636-640. (https://doi.org/10.1111/j.14321033.1996.0636r.x)

Reinert M, Calvete J, Sanz L \& Topfer-Petersen E 1997 Immunohistochemical localization in the stallion genital tract, and topography on spermatozoa of seminal plasma protein SSP-7, a member of the spermadhesin protein family. Andrologia 29 179-186. (https://doi. org/10.1111/j.1439-0272.1997.tb00314.x)

Robbins M \& Kennedy PE 2001 Buyer behaviour in a regional thoroughbred yearling market. Applied Economics 33 969-977. (https:// doi.org/10.1080/00036840010002529)

Ross P, Kan FW, Antaki P, Vigneault N, Chapdelaine A \& Roberts KD 1990 Protein synthesis and secretion in the human epididymis and immunoreactivity with sperm antibodies. Molecular Reproduction and Development 26 12-23. (https://doi.org/10.1002/mrd.1080260104)

Sabeur K, Vo AT \& Ball BA 2000 Effects of angiotensin II on the acrosome reaction in equine spermatozoa. Journal of Reproduction and Fertility 120 135-142. (https://doi.org/10.1530/jrf.0.1200135)

Sakkas D, Leppens-Luisier G, Lucas H, Chardonnens D, Campana A, Franken DR \& Urner F 2003 Localization of tyrosine phosphorylated proteins in human sperm and relation to capacitation and zona pellucida binding. Biology of Reproduction 68 1463-1469. (https://doi. org/10.1095/biolreprod.102.011023)

Samanta L, Swain N, Ayaz A, Venugopal V \& Agarwal A 2016 Posttranslational modifications in sperm proteome: the chemistry of proteome diversifications in the pathophysiology of male factor infertility. Biochimica et Biophysica Acta 1860 1450-1465. (https://doi. org/10.1016/j.bbagen.2016.04.001)

Sanz L, Calvete JJ, Mann K, Schäfer W, Schmid ER, Amselgruber W, Sinowatz F, Ehrhard M \& Töpfer-Petersen E 1992 The complete primary structure of the spermadhesin AWN, A zona pellucida-binding protein isolated from boar spermatozoa. FEBS Letters 300 213-218. (https://doi. org/10.1016/0014-5793(92)80848-B)

Sawyer DE, Mercer BG, Wiklendt AM \& Aitken RJ 2003 Quantitative analysis of gene-specific DNA damage in human spermatozoa. Mutation Research 529 21-34. (https://doi.org/10.1016/S0027-5107(03)00101-5)

Schrimpf R, Dierks C, Martinsson G, Sieme H \& Distl O 2014 Genomewide association study identifies phospholipase $\mathrm{C}$ zeta 1 (PLCz1) as a stallion fertility locus in Hanoverian Warmblood horses. PLoS ONE 9 e109675. (https://doi.org/10.1371/journal.pone.0109675)

Shiba K, Baba SA, Inoue T \& Yoshida M 2008 Ca2+ bursts occur around a local minimal concentration of attractant and trigger sperm chemotactic response. PNAS $10519312-19317 . \quad$ (https://doi.org/10.1073/ pnas.0808580105)

Shiva M, Gautam AK, Verma Y, Shivgotra V, Doshi H \& Kumar S 2011 Association between sperm quality, oxidative stress, and seminal antioxidant activity. Clinical Biochemistry 44 319-324. (https://doi. org/10.1016/j.clinbiochem.2010.11.009)

Somashekar L, Selvaraju S, Parthipan S, Patil SK, Binsila BK, Venkataswamy MM, Karthik Bhat S \& Ravindra JP 2017 Comparative sperm protein profiling in bulls differing in fertility and identification of phosphatidylethanolamine-binding protein 4, a potential fertility marker. Andrology 5 1032-1051. (https://doi.org/10.1111/andr.12404)

Suzuki YJ, Carini M \& Butterfield DA 2010 Protein carbonylation. Antioxidants and Redox Signalling 12 323-325. (https://doi.org/10.1089/ ars.2009.2887)

Swegen A, Curry BJ, Gibb Z, Lambourne SR, Smith ND \& Aitken RJ 2015 Investigation of the stallion sperm proteome by mass spectrometry. Reproduction 149 235-244. (https://doi.org/10.1530/REP-14-0500)

Swegen A, Lambourne SR, Aitken RJ \& Gibb Z 2016 Rosiglitazone improves stallion sperm motility, ATP content, and mitochondrial function. Biology of Reproduction 95 107. (https://doi.org/10.1095/ biolreprod.116.142687)

Szczygiel MA \& Ward WS 2002 Combination of dithiothreitol and detergent treatment of spermatozoa causes paternal chromosomal damage. Biology of Reproduction 67 1532-1537. (https://doi.org/10.1095/ biolreprod.101.002667)

Takahashi T 2015 The effect of age on the racing speed of thoroughbred racehorses. Journal of Equine Science 26 43-48. (https://doi.org/10.1294/ jes.26.43)

Thompson SD, Prahalad S \& Colbert RA 2016 Chapter 5 - integrative genomics A2 - Petty, Ross E. In Textbook of Pediatric Rheumatology, 7th ed. Eds RM Laxer, CB Lindsley \& LR Wedderburn. Philadelphia: W.B. Saunders.

Töpfer-Petersen E, Ekhlasi-Hundrieser M, Kirchhoff C, Leeb T \& Sieme H 2005 The role of stallion seminal proteins in fertilisation. Animal Reproduction Science 89 159-170. (https://doi.org/10.1016/j. anireprosci.2005.06.018)

Topfer-Petersen E, Romero A, Varela PF, Ekhlasi-Hundrieser $M$, Dostalova Z, Sanz L \& Calvete JJ 1998 Spermadhesins: a new protein family. Facts, hypotheses and perspectives. Andrologia 30 217-224. (https://doi.org/10.1111/j.1439-0272.1998.tb01163.x)

Torregrosa N, Domínguez-Fandos D, Camejo MI, Shirley CR, Meistrich ML, Ballescà JL \& Oliva R 2006 Protamine 2 precursors, protamine 1/ protamine 2 ratio, DNA integrity and other sperm parameters in infertile patients. Human Reproduction 21 2084-2089. (https://doi.org/10.1093/ humrep/del114)

Tourmente M, Villar-Moya P, Rial E \& Roldan ER 2015a Differences in ATP generation via glycolysis and oxidative phosphorylation and relationships with sperm motility in mouse species. Journal of Biological Chemistry 290 20613-20626. (https://doi.org/10.1074/jbc.M115.664813)

Tourmente M, Villar-Moya P, Varea-Sanchez M, Luque-Larena JJ, Rial E \& Roldan ER 2015b Performance of rodent spermatozoa over time is enhanced by increased ATP concentrations: the role of sperm competition. Biology of Reproduction 93 64. (https://doi.org/10.1095/ biolreprod.114.127621)

Tsatsanis C, Bobjer J, Rastkhani H, Dermitzaki E, Katrinaki M, Margioris AN, Giwercman YL \& Giwercman A 2015 Serum miR-155 as a potential biomarker of male fertility. Human Reproduction $\mathbf{3 0}$ 853-860. (https://doi.org/10.1093/humrep/dev031)

Ward WS \& Coffey DS 1991 DNA packaging and organization in mammalian spermatozoa: comparison with somatic cells. Biology of Reproduction 44 569-574. (https://doi.org/10.1095/biolreprod44.4.569)

Yanagimachi R 1970 The movement of golden hamster spermatozoa before and after capacitation. Journal of Reproduction and Fertility 23 193-196. (https://doi.org/10.1530/jrf.0.0230193)

Yuan S, Schuster A, Tang C, Yu T, Ortogero N, Bao J, Zheng H \& Yan W 2016 Sperm-borne miRNAs and endo-siRNAs are important for fertilization and preimplantation embryonic development. Development 143 635-647. (https://doi.org/10.1242/dev.131755)

Zalata A, El-Samanoudy AZ, Shaalan D, El-Baiomy Y, Taymour M \& Mostafa T 2012 Seminal clusterin gene expression associated with seminal variables in fertile and infertile men. Journal of Urology 188 1260-1264. (https://doi.org/10.1016/j.juro.2012.06.012)

Zhang X, San Gabriel M \& Zini A 2006 Sperm nuclear histone-toprotamine ratio in fertile and infertile men: evidence of heterogeneous subpopulations of spermatozoa in the ejaculate. Journal of Andrology 27 414-420. (https://doi.org/10.2164/jandrol.05171)

Received 7 February 2019

First decision 14 March 2019

Revised manuscript received 23 April 2019

Accepted 20 May 2019 